\title{
Mabc-2 Transcultural Adaptation and Evaluation of Children Aged 7 to 10 Years With Autistic Spectrum Disorder
}

\author{
Carolina Lourenço Reis Quedas, ${ }^{1}$ Maria Eloisa Famá D'Antino, ${ }^{2}$ \\ Ricardo Henrique R. Quintas, Raquel Cymrot, ${ }^{2}$ Marina Monzani Rocha, ${ }^{2}$ \\ Silvana Maria Blascovi-Assis²
}

\section{ABSTRACT}

Motor development is not part of the diagnostic criteria for people with Autistic Spectrum Disorder (ASD), but it must be considered in the assessment and intervention process of ASD children. Objectives: To carry out translation and transcultural adaptation to Portuguese / Brazil version of the Movement Assessment Battery for Children-2 (MABC-2) for the 7-10 year age group and test the version translated into children with ASD. Method: The study was applied to 41 boys with ASD and correlated with Raven's Colored Progressive Matrices test (CPM). Results and Discussion: It was observed that the correlations with the standard scores between the domains assessed by MABC- 2 and the CPM results showed to be median Manual Dexterity $(r=0.454, p=0.012)$ and Balance $(r=0.324, p=0.081)$ and small for Aiming and Catching $(r=0.170, p=0.368)$. By the traffic light system, $83 \%$ of those evaluated were classified in the red zone, with significant motor deficits. Conclusion: Correlation tests showed that the degree of intelligence seems to influence motor performance. The relevance of studies and assessments about the motor area for ASD children is considered, minimizing the factors that may interfere with the motor tasks performance.

Keywords: Autism; motor dexterity; motor activity; disability assessment.

\section{ADAPTAÇÃO TRANSCULTURAL DO MABC-2 E AVALIAÇÃO DE CRIANÇAS DE 7 A 10 ANOS} COM TRANSTORNO DO ESPECTRO AUTISTA

\section{RESUMO}

O desenvolvimento motor não faz parte dos critérios diagnósticos de pessoas com Transtorno do Espectro Autista (TEA), porém deve ser considerado no processo de avaliação e intervenção da criança com esse distúrbio. Objetivos: Realizar tradução e adaptação transcultural para a versão Português/Brasil da escala Movement Assessment Battery for Children-2 (MABC-2), para a faixa etária de 7 a 10 anos e testar a versão traduzida em crianças com TEA. Método: 0 estudo foi aplicado em 41 meninos com TEA e correlacionado com o teste das Matrizes Progressivas Coloridas de Raven (MPR). Resultados e Discussão: Observou-se que as correlações com os escores padrão entre os domínios avaliados pela MABC-2 e os resultados das MPR mostraram-se moderadas para Destreza Manual $(r=0,454, p=0,012)$ e Equilíbrio $(r=0,324, p=0,081)$ e pequena para Jogar e Pegar $(r=0,170, p=0,368)$. Pelo sistema semáforo, $83 \%$ dos avaliados classificados na zona vermelha, com déficits motores significativos. Conclusão: $\mathrm{O}$ uso da MABC-2 possibilitou identificar algumas adaptações que podem favorecer a avaliação motora no grupo estudado. Os testes de correlação mostraram que o grau de inteligência parece influenciar o desempenho motor. Considera-se a relevância de estudos e avaliações na área motora para crianças com TEA, minimizando-se os fatores que podem interferir no desempenho de tarefas motoras.

Palavras-chave: Autismo; destreza motora; atividade motora; avaliação de deficiência.

RECEBIDO EM: 9/12/2020

MODIFICAÇÕES SOLICITADAS EM: 29/4/2021

ACEITO EM: 26/6/2021

\footnotetext{
${ }^{1}$ Autora correspondente. Universidade Anhanguera. Rua Barão de Itapetininga, 298- República. CEP 01045-001. São Paulo/ SP, Brasil. http://lattes.cnpq.br/4663810522973840. http://orcid.org/0000-0001-7846-9325. carolinaquedas@gmail.com

2 Programa de Pós-Graduação em Distúrbios do Desenvolvimento na Universidade Presbiteriana Mackenzie (UPM), São Paulo/SP, Brasil.
} 


\section{INTRODUCTION}

Autistic Spectrum Disorder (ASD) is characterized by a neurodevelopmental disorder that causes social, behavioral, and communication impairments ${ }^{1}$. Motor development is not part of the diagnostic criteria; however, it is no less important than other aspects and must be considered in the assessment and intervention process of ASD children.

ASD is characterized by its significantly atypical development concerning social interactions and communication, as well as the presence of a restricted markedly repertoire of activities and interests. Such impairments appear before the age of three, becoming more noticeable throughout development. In individuals affected by this disorder, there is a qualitative difficulty in the relationship and communication regularly with other people since early childhood. ${ }^{1}$

Motor impairment is neurological comorbidity associated with epilepsy, sleep disorders, in addition to deficits, stereotypes, fine and global motor coordination impairment and gait disability. Besides, it is stated that these signs could be present in the first years of life in cases of ASD. ${ }^{2,3}$

The scarcity of studies related to motricity for the ASD public makes this an important research area and with a vast study field, mainly for professionals who work with human motricity, such as Physical Education, Occupational Therapists, and Physiotherapists professionals, who, in their specificities, can assist ASD individuals in early intervention, in the prevention and in the application of activities that minimize their motor deficits.

Among the motor assessment instruments, the Movement Assessment Battery for Children 2 (MABC-2) appears as one of the most used for children and young people with ASD. MABC-2 is characterized by a scale that evaluates children and adolescents from 3 to 16 years old and is divided into three skill areas: manual dexterity, ball skills, and static/dynamic balance. It is used to assess and identify risks for motor development. It classifies the evaluation through a traffic light system that describes motor performance comparing to the percentiles established as the development standard described in its manual ${ }^{4,5}$.

In 2014, a study of transcultural translation and analysis of aspects of validity and reliability of MABC- 2 in Brazil was published, with a sample of 844 children whose performance standard was compared to parameters reported in the test manual6.

In another article, an agreement test was performed between the MABC-2 motor test and the MABC-2 checklist, controlled by the Developmental Coordination Disorder Questionnaire (DCDQ-BR) as a gold reference, in 350 typical children aged between 7 and 10 years in the cities of Florianópolis-SC and Manaus-AM. The agreement between the instruments was assessed using Spearman's correlation test and simple linear regression. The results showed a positive correlation between the instruments, and it was possible to observe concurrent validity pieces of evidence between MABC-2 and DCDQ-BR, suggest-

Editora Unijuí - Revista Contexto \& Saúde - ISSN 2176-7114 - v. 21, n. 44, out./dez. 2021 
ing that MABC-2 can be used as an indicator of developmental coordination disorder $^{7}$

MABC-2 was adapted in Brazil to evaluate a group of 40 children with low vision, with results that indicated improvement in the evaluation of motor performance, possibly related to the maximization of visual function and the use of other systems (touch, hearing) to provide information, with reasonable reproducibility rates in this population ${ }^{8}$.

In another study, the motor performance of 28 children and adolescents was evaluated using MABC-2, 14 with ASD and 14 with typical development aged between 3 to 16 years. They checked manual dexterity, ball skills, and balance. As a result, they found deficits in global motor performance in all aspects evaluated, suggesting that more extensive studies with larger groups could bring higher knowledge about the Brazilian population with ASD.

MABC-2, which started to be commercialized in Brazil in 2020, has been used in the country in several works, with participants with typical development, such as children of preschool and school-age ${ }^{10}$ or with audiences in specific clinical conditions ${ }^{8,9}$.

It is also noteworthy that this scale has been used in different countries, with translations and cultural adaptations made available to the scientific community that studies aspects of motor development. Researchers investigated the appropriateness of using the motor test in different countries, such as China, Japan, the Netherlands, Belgium, and Sweden, with the original version validation $^{10 .}$

This work aimed to carry out translation and transcultural adaptation from the Portuguese/Portugal to Portuguese/Brazil version of the Movement Assessment Battery for Children-2 (MABC-2), Band-2 scale for the 7 to 10 years old age group and test the translated version into male children with ASD, checking the need for adaptations of the scale for this audience, as well as the influence of the level of intelligence on the scores of motor tasks.

\section{METHODS}

\section{Participants}

This study was submitted to and approved by the Ethics Committee of Mackenzie Presbyterian University under process CEP no 1.1717.700 of September 2016 and CAAE no 59046816.7.0000.0084. After the invitation and clarification of voluntary participation, all guardians signed the Free and Informed Consent Form (ICF) for Parents or Guardians, as well as those responsible for the collaborating institutions. Participants with ASD were asked to agree to the evaluations, respecting the child's desire to perform the tests or not.

Seventy-six male children, aged between 7 and 10 years old, who presented an Autism Spectrum Disorder report, were initially selected by the participating schools and institutions. These schools belong to the public network of São Paulo, Embu das Artes, Private School Institutions that had specialized educational services for the public with ASD (in the regions of São Bernardo, Sorocaba, 
and Capital) and a multidisciplinary institution for people with disabilities also in the region of São Paulo.

The choice for the male gender was due to the prevalence levels of ASD in the proportion of $4: 1$ for boys ${ }^{11}$, thus maintaining a greater homogeneity of the sample.

Inclusion Criteria: Male children who had a medical diagnosis of ASD based on the DSM-5 and who matched the first five figures of the Raven's Colorful Progressive Matrices test were included in the study.

The study was carried out in three stages: Stage 1: translation and transcultural adaptation of the MABC-2 scale from Portuguese from Portugal to Brazilian Portuguese; Stage 2: Evaluation of 10 participants with ASD by translated MABC-2 for analysis of inter and intra-examiners reliability and proposal of adaptations for the use of the instrument with this population; Stage 3: evaluation of 30 children who presented an ASD report, who was indicated by participating schools and institutions. Raven's Colorful Progressive Matrices (CPM) and MABC2 tests were applied for inclusion criteria.

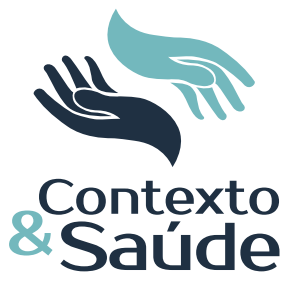

Authorization with the MABC-2 copyright holder (Pearson)

Translation and Adaptation Evaluation Sheet Banda 02 Portuguese (Portugal) p / Portuguese (Brazil)

- a) Permission; b) Translation and agreement; c) Reverse translation (or back-translation) and concordance; c) Review of the final version; e) Evaluation

\begin{tabular}{|c|}
\hline $\begin{array}{l}\text { Back-translation and Analysis Committee of Judges } \\
\text { - Specialist Judge (Portuguese with proficiency in the English language) }\end{array}$ \\
\hline $\begin{array}{c}\text { Evaluation of } 10 \text { people diagnosed with ASD } \\
\text { - Analysis of the difficulties presented during the application of the scale }\end{array}$ \\
\hline $\begin{array}{l}\text { Application of adaptation suggestions } \\
\text { - Evaluation of } 41 \text { people with ASD }\end{array}$ \\
\hline
\end{tabular}

Source: author

\section{Procedures}

Initially, Raven's Colorful Progressive Matrices (CPM) was applied to verify children's intellectual development. This test consists of presenting a matrix of figures, in which there is a pattern ${ }^{12}$.

It is a test based on visual stimuli, so children with Low Vision or Blindness should be excluded from the study. CPMs can be applied individually or collecti- 
vely, with or without a time limit. When applied, with a time limit, the application should last 40 minutes.

The Raven's test was used in its colored Brazilian version in 793 children aged between 7 and 8 years old. It is presented as a booklet composed of three sets of items $(A, A B \text {, and } B)^{13}$. Each item is a drawing with a missing part, allowing only one correct answer among the six options presented to the child. One point is awarded for each correct answer. The sum of the correct answers determines the total result.

The test scores include: intellectually superior; definitely above average; intellectually average; definitely below average; and intellectually deficient.

MABC-2 is a test consisting of eight tasks that involve skills divided into manual dexterity (basing the string, drawing a track and fitting the pins), aiming and catching (throwing the ball on the wall and catching with both hands, and throwing a beanbag at a target) and balance (walk with one foot in front of the other in a line, stand with one foot on a small board and jump on 5 rugs)

Time is clocked and recorded in seconds, number of errors and number of correct answers and, depending on the task, indicating the degree of motor difficulty. Standard scores can vary from 1 to 19 , with the corresponding percentile. When the result shows performance below the 5 th percentile, difficulty in movement is assumed; between the 6th and 15th percentiles, there is an indication of risk of having motor difficulties and requires monitoring. When the results fall within the 16th percentile, it is assumed that the child does not have any motor difficulties. ${ }^{4}$

The percentage scores of the test are described as a traffic light scoring system, distributed in red, yellow, and green zones (chart 2).

Table 2 - MABC-2 Traffic Light System

\begin{tabular}{|l|c|c|}
\hline \multicolumn{1}{|c|}{ Classification } & Percentile Range & Description \\
\hline Red Zone & $=$ or $<5$ & Significant motor difficulty \\
Yellow Zone & Between 6 and 15 & $\begin{array}{c}\text { Risk of having motor difficulties and } \\
\text { requires monitoring }\end{array}$ \\
Green area & $>15$ & No motor difficulties \\
\hline
\end{tabular}

The test is divided into three sections by age group with eight tasks distributed according to the proposed bands:

- Band 1: 3 to 6 years;

- Band 2: 7 to 10 years;

- Band 3: 11 to 16 years.

For this work, Band 2 was used with children from 7 to 10 years old, with prior authorization from Pearson publisher, through a signed contract. 
Moreover, to the evaluated items that generate the scores that code the traffic light zones, the scale offers the option of a qualitative assessment, which allows therapists to complement the numerical results of the performance test with clinical observations. The child's motor performance can be recorded through items marked by the observer and that refers to "how the child performs the requested activity". For each scored item, observations can be made about posture control and necessary adjustments to the task requirements. In addition, some items can be recorded, such as influences on performance (disorganization, passivity, shyness, or impulsivity) and physical factors that can affect movement (problems with vision, hearing, weight and height analysis, and postural and anatomical changes). The complete record also presents a summary, which should include the child's assessment and space to outline an intervention plan in different environments as the school, health services, and the community.

\section{Statistical analysis}

The data were analyzed using the Minitab statistical program, and the significance level was set at $p \leq 0.05$

\section{RESULTS}

\section{Step 1: Translation and Adaptation of the MABC-2, Band 2 Scale}

The choice of MABC-2 for this study was due to the relevance of this instrument for the area of motor assessment in the international scientific community.

Before a group of researchers starts translating the instrument, it is necessary to consider the need for access to this evaluation model and how much it meets the objectives of the work. Then, permission must be obtained from the appropriate source, that is, the editor or that instrument author ${ }^{14}$.

Five steps must therefore be followed for a good translation: a) Permission; b) Translation and agreement; c) Reverse translation (or back-translation) and concordance; c) Review of the final version; e) Evaluation ${ }^{14 .}$

The steps followed in the present study included the recommendations described, based on standardized precepts ${ }^{15}$.

Permission: Permission for translation was obtained by contacting Pearson Publisher, from England, which initially authorized the translation and adaptation of the Portuguese version, from Portugal to the Brazilian Portuguese language. The permission agreement was dated 6/1/2017. In the contract, the authors undertook to assign the translation rights to the Publisher after using the scale. The researchers were granted the right to use 50 assessments for Band 2, free of charge to the researchers. From then on, the translation itself took place, which occurred under the literature recommendations for the instrument translation processes. ${ }^{15}$

Translation: The translation, validation, and adaptation carried out in Portugal were the basis for the translation into Brazilian Portuguese. However, there was a need for transcultural adaptation. Two researchers did the translation, in-

Editora Unijuí - Revista Contexto \& Saúde - ISSN 2176-7114 - v. 21, n. 44, out./dez. 2021 
dependently. One translator had knowledge of the instrument's content, designated as $T 1$, and the other translator, with previous experience in instrument translation, did not know the content of the instrument, being designated as $T 2^{16 .}$

Synthesis of Translations: Three specialists, subsequently, performed the analysis and synthesis of the two translations (T1 and T2) to correct possible discrepancies, reaching the first version of the translation. Some questions from the experts were resolved by consulting the original English version.

Back-translation: The synthesized and translated version was sent to a translator of Portuguese nationality, with mastery of the English language, resident in Brazil. The translation was checked based on the Portuguese and English versions for later finalization by the same committee of three specialists and preparation of the final version. It was verified that the translated version reflected the same content as the original version, ensuring the consistency of the translation.

A multidisciplinary committee was formed composed of three doctors with experience in translation and transcultural adaptation processes, which evaluated the equivalence between the Portuguese and Brazilian versions, according to the recommendations. ${ }^{17}$. These equivalences were considered: semantic, idiomatic, experiential, and conceptual.

The translation and back-translation resulted in a final version with some modifications suggested by the judges. This version was sent to Pearson Publisher and later used in the evaluation of participants with ASD.

\section{Step 2: Pilot study and proposals for adapting the MABC-2 scale for children with ASD}

Forty-one boys diagnosed with ASD participated in the study, 10 in the first stage and 31 in the second stage, in the metropolitan region of São Paulo. Data analysis was performed using statistical tests for analysis of instrument reliability and statistical correlation.

In this stage, $\mathrm{G} 1$ evaluations were performed, composed of 10 boys with ASD, with an average age of 8.8 years. The evaluations were filmed so that two evaluators with experience in the application of the instrument could score the tests for later analysis of inter and intra- examiner reliability, in addition to collecting suggestions for improving the applicability of the instrument.

The three tasks proposed by the scale for Manual Dexterity (MD), two tasks for Aiming and Catching (A\&C), and three for Balance (B) were evaluated.

The inter-examinar reliability results showed that for the tasks of MD1, MD3, A\&C1 and B2, values of $r=1.00$ (almost perfect) were found; for MD2 $r=$ $0.753 ; A \& C r=0.756 ; B 1 r=0.841$ and B3 $r=0.639$ (substantial) and a total score of $r=0.677$, substantial ${ }^{18}$.

The intra-examiner reliability was $100 \%$, with no differences in assessments in the first test for the second.

For all tasks, the need to increase the number of training attempts was identified. All the considerations that were relevant to the execution process were sent to the next stage of the application. It should be noted that the fle- 
xibility in the application of the scale was limited to the training that precedes the scoring of the tasks, maintaining the rigor expected for the application of the tests. As mentioned earlier, all evaluations were filmed, and this was considered an appropriate adaptation for a better analysis of the results of the tasks.

The results in group 1 were $80 \%$ in the red zone, 10\% in the yellow zone and $10 \%$ in the green zone, showing a significant delay for the public with autism at this stage of the study.

\section{Step 3: Motor assessment of children with ASD using the MABC-2 scale, the Brazilian version}

In this stage, the CPM and MABC-2 instruments were applied to 31 children who participated in $\mathrm{G} 2$, with a mean age of 8.74 years. The data were analyzed using the Minitab statistical program and the significance level was set at $p \leq 0.05$.

Table 1 presents the descriptive analysis of the quantitative variables. It was observed that $3.23 \%$ (1) were in the intellectually superior range, $12.90 \%$ (4) above the average, $22.58 \%$ (7) intellectually on average, $29.03 \%$ (9) intellectually deficient, and $32.26 \%$ (10) of the sample of evaluated children were classified, by the CPM test, as definitely below the intellectual average. Regarding the manual preference of these individuals, $58.06 \%$ had a right-handed preference $(n=18)$, while $41.94 \%$ were left-handed $(n=13)$.

Table 3 - Descriptive analysis of quantitative variables $(n=31)$

\begin{tabular}{ccccc}
\hline Raven & $\mathbf{n}$ & Percent & MP & Percent \\
\hline 1 & 9 & 29.03 & $\mathrm{RH}=18$ & 58.06 \\
2 & 10 & 32.26 & $\mathrm{LH}=13$ & 41.94 \\
3 & 7 & 22.58 & & \\
4 & 4 & 12.90 & & \\
5 & 1 & 3.23 & & \\
\hline
\end{tabular}

Raven: Raven's Colorful Progressive Matrices n = number; MP = Manual Preference RH= right-handed; $\mathrm{LH}=$ left-handed

$$
\text { Source: the authors. }
$$

MABC-2 was applied considering the suggestions of the second stage. The results are classified by domain concerning the CPM, and total score through the traffic light system according to the proposed objectives of this work.

It is noteworthy that the application occurred in 31 boys. However, for statistical data, a child was excluded because he was identified in the sample as an outlier participant, who distanced himself considerably above the average of the others, thus obtaining greater homogeneity of the sample, treated statistically with $n=30$. Nonparametric statistics tests and correlations were applied by the Pearson test. The classification of the group of 30 children evaluated maintained a concentration of $83 \%(n=25)$ in the red zone, followed by $14 \%(n=4)$ in the yellow zone and $3 \%(n=1)$ in the green zone.

The CPM classification showed a high concentration in the lower and below-average intelligence ranges in $64 \%$ of the participants ( $n=19), 23 \%$ with average intelligence $(n=7)$, and $13 \%$ above the average or higher $(n=4)$. 
To facilitate the reading of the following tables, which deal with the correlations, the abbreviations for CPM (Raven's Progressive Matrices), MD1, 2.3 (Manual Dexterity), A \& C 1.2 (Aiming and Catching), and B 1, 2.3 (Balance) were used.

The analysis of the magnitude of the correlations obtained by the Pearson test is presented based on Cohen's parameters. ${ }^{19}$ The classification of this magnitude is defined as small for $0.10<r<0.29$, average $0.30<r<0.49$ and large for $0.50<r<1.00^{18}$. In this correlation analysis, the $p$-value $\leq$ of 0.05 was adopted as statistically significant.

The results indicated that the correlations with the standard scores between the domains evaluated by MABC and the results of the CPM showed to be mean for $M D(r=0.454$, with $p=0.012)$ and $B(r=0.324$, with $p=0.081)$ and small for $A \& C(r=0.170$, with $p=0.368)$.

The correlation between the MD and $A \& C$ domains was medium $(r=$ 0.368 , with $p=0.046) ; M D$ and $B$, large $(r=0.566$, with $p=0.001)$ and $A \& C$ and $B$, large $(r=0.526$, with $p=0.003)$.

The correlations between the standard Raven test score and the MABC-2 domains evaluated are shown in Figure 1, with the Dispersion Matrix.

Figure 1 - Scatter matrix of correlations between domains and the CPM Standard Score

\section{Scatter matrix of correlations}

Standard score CPM

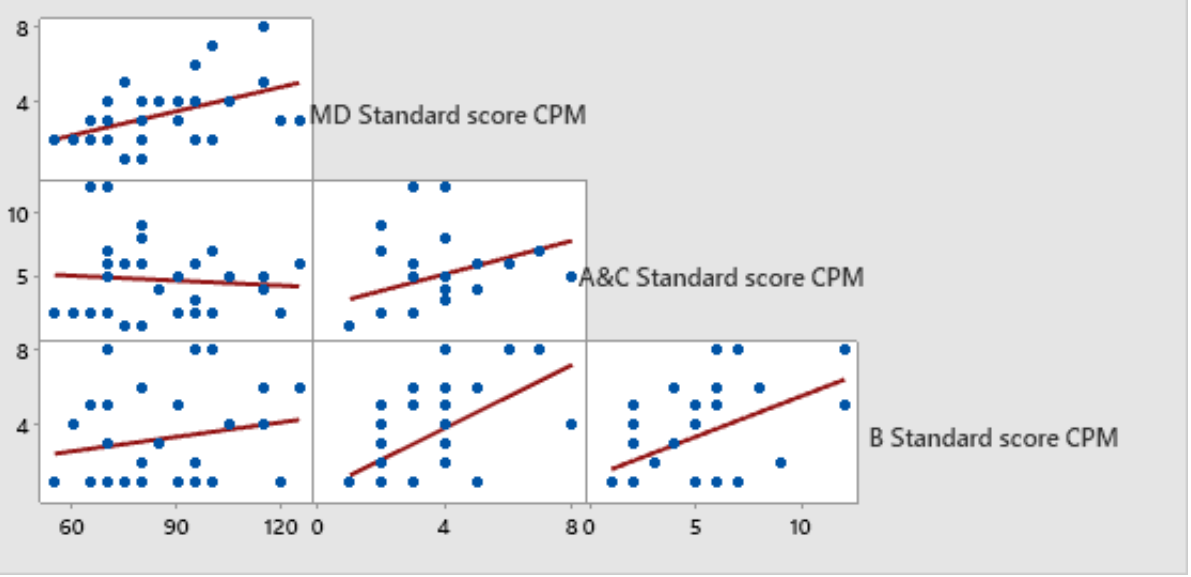

Source: The author.

The correlation between the total score, which represents the classification in the traffic light system that includes the three domains, and the CPM, which represents the level of global intelligence, was low $(r=0.232$, with $p=$ 0.217). 
Figure 2 - Correlation Total Score vs. Standard CPM Score

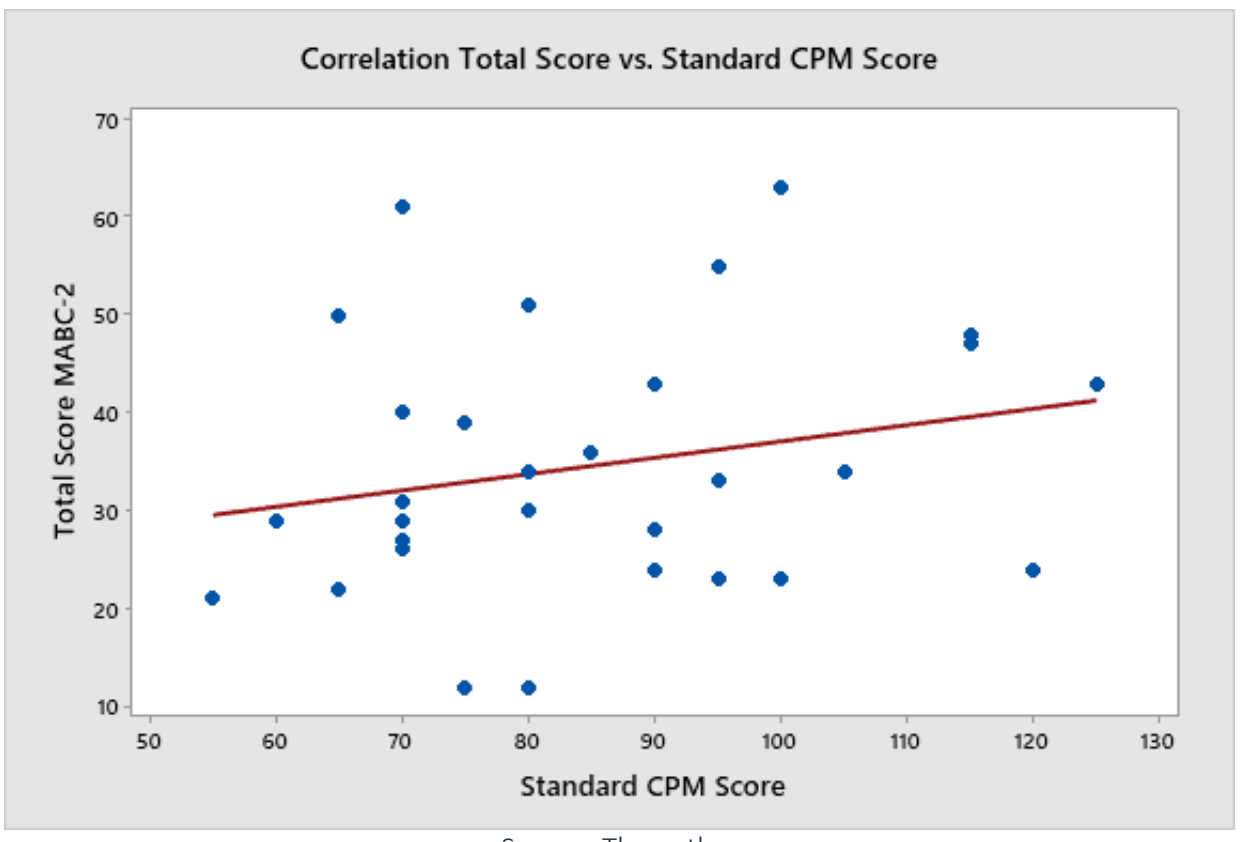

Source: The author.

For the MD domain, tasks 1,2 and 3 presented mean correlations for MD1 $(r=0.363, p=0.049)$ and MD2 $(r=0.396, p=0.030)$ and small for MD3 $(r=$ $0.220, p=0.242$, respectively). For the $A \& C$ domain, the tasks showed correlations: small for $A \& C 1(r=-0.091, p=0.631)$ and for $A \& C 2(r=-0.086, p=0.652)$. The $B$ domain showed correlations: large for $B 1(r=0.537, p=0.002)$ and small for $B 2(r=-0.011, p=0.953)$ and $B 3(r=0.119, p=0.532)$. According to Figures $3,4,5$.

Figure 3 - Correlations between MD X CPM tasks
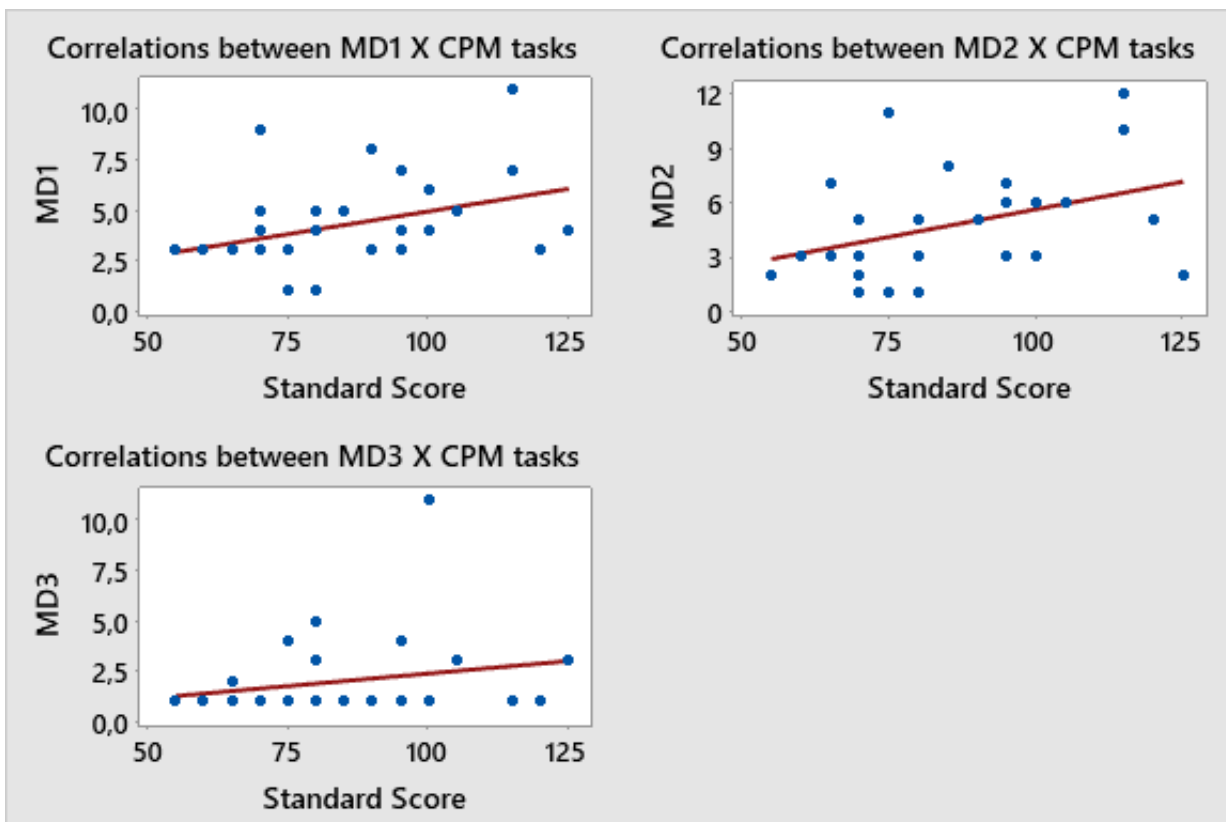

Source: The author. 
Figure 4 - Correlations between J\&P X MPR tasks

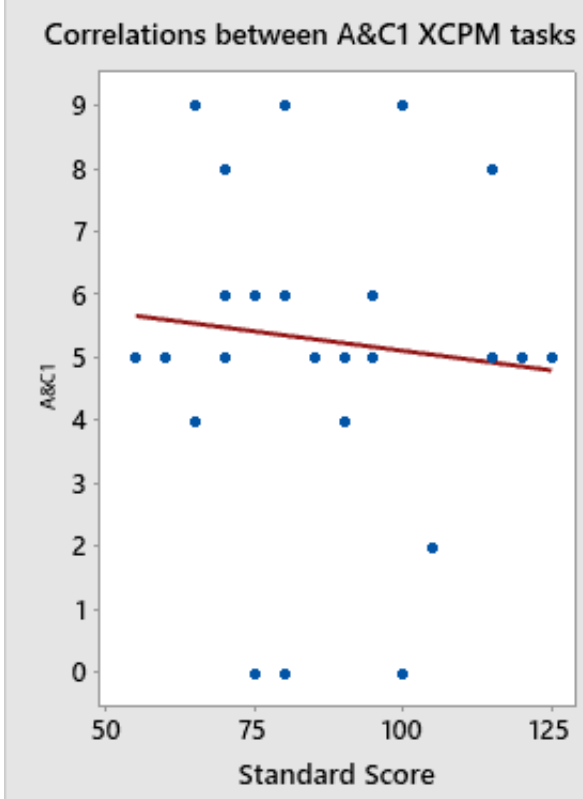

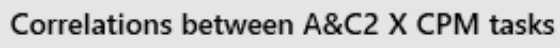

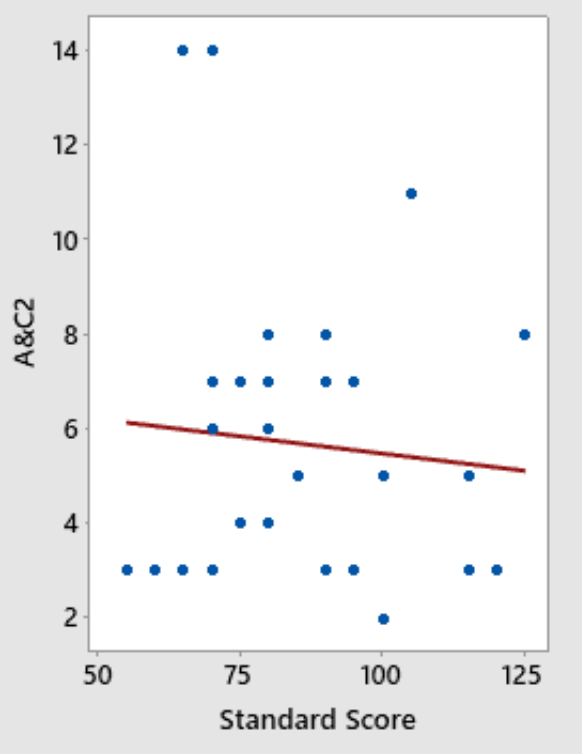

Figure 5 - Correlations between B X CPM tasks
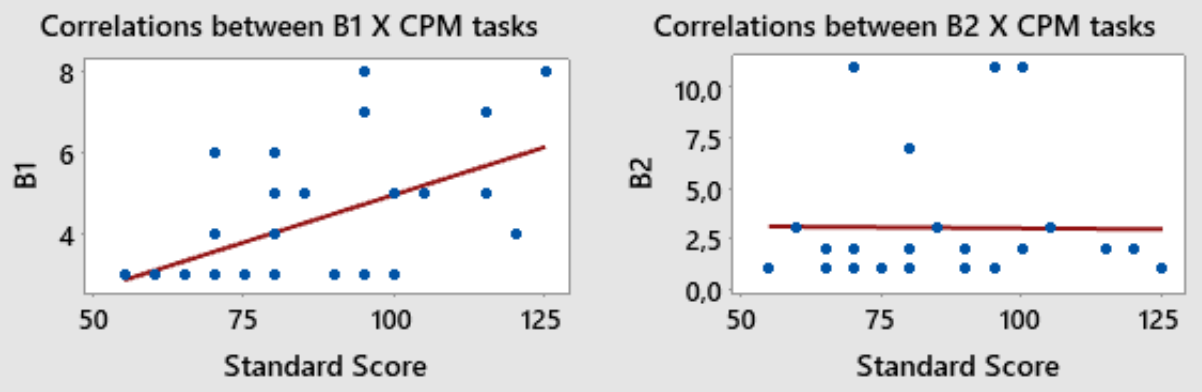

Correlations between B3 X CPM tasks

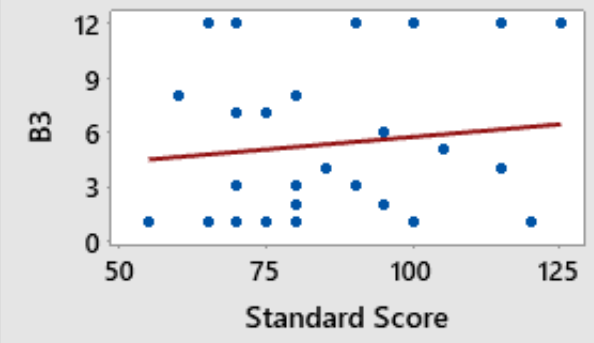

Source: The author.

\section{DISCUSSION}

The translation of the MABC-2 instrument carried out in this study occurred according to the recommendations of the literature following the phases of translation, back-translation, and transcultural adaptation. ${ }^{15}$ It was authorized by Pearson Publisher, which holds the marketing rights and licenses to use the test. 
Some evidence of validity could be obtained given the high levels of intra and inter-examiner reliability ( $>90 \%)$. MABC- 2 is already being used for audiences with ASD in several recent international studies that compare nutritional issues and motor skills, ${ }^{20}$ or in the comparison of social issues and motor performance in different audiences such as Intellectual Disability and Autism. ${ }^{21}$ It was found that the results in Phase 2, with 10 participants and in Phase 3 with 30 participants, did not show differences in the traffic light system classifications, ranking respectively in the range of $80 \%$ and $83 \%$ in the red zone in stages 1 and 2 , approaching the current literature that revealed about $87 \%$ of North American children with ASD has significant motor deficits ${ }^{22}$.

In both phases, a significant motor deficit was evidenced for the population with ASD even with changes in the way the test was applied, such as more extended time to practice the tasks, motivation to tasks, more extended timespace between tasks, not influencing the results. This finding suggests that possibly ASD children, regardless of the suggested adaptations, have persistent motor deficits.

Studies state that the relevance of motor changes in ASD children has been camouflaged for a long time by the need to pay attention to the social, emotional, and communication aspects that are characteristic in this group of children ${ }^{23}$. The authors report that one of the hypotheses of motor alterations in ASD may be associated with the neurophysiological mechanisms that involve mirror neurons, which remain unclear.

Another study showed that children under 6 with ADS $35.4 \%$ of the studied sample ( $\mathrm{N}=2,084 ; 81.2 \%$ men, $18.8 \%$ women) met the criteria for motor difficulties, a rate almost as common as intellectual disability (37.7\%). ${ }^{24}$ This study demonstrates that motor difficulties are a prominent feature of the autism phenotype, requiring further consideration both in the diagnostic criteria and in the assessment of autism.

A study carried out with thirteen boys and two girls with ASD, with a mean age of 8.11 years, level with an average IQ of 91 , found in imitation tasks a performance significantly impaired when compared with children with typical development. ${ }^{23}$ This fact can also justify the low performance of the motor tasks of the group studied here since even with more detailed explanations and demonstration of the tasks, the difficulty in executing the requested actions and movements was persistent.

Studies reinforce the findings of the present study, which involved 30 children with a mean age of 8.74 years, but with levels of intelligence below the average according to the CPM test ${ }^{23}$. It is suggested that other studies of adaptation concerning adaptation scales consider and discuss motor performance with an emphasis on the neurophysiological mechanisms that surround motor activity even with the use of visual imaging protocols.

The data showed that there is no significant correlation $(p<0.05)$ between the standard score in the global intellectual coefficient and the performance in the MABC-2 three domains, indicating that, regardless of the level of intelligence, the children in this study had significant motor deficits. Regarding the 
specificities of each task, the analyzes indicate a mean correlation between CPM and MD1 ( $p=0.049)$ and MD2 ( $p=0.030)$ and a large correlation in B1 activity $(p=0.002)$, with significant values for both considering the significance level of $p \leq 0.05$.

The MD1 activity aims to check the participant's manual dexterity by inserting pins, picking them up one by one, without dropping and without the help of the other hand, as quickly as possible, without breaking the rules. The MD2 activity aims to baste the cord, without leaving the arms resting on the table as a form of support; the line must be fitted in the holes correctly and continuously and needs to be carried out quickly. The B1 task had the characteristic of verifying the maximum time that the child was in the single-legged position on top of a balance beam. Both tasks were correlated with the CPM, so the better the intellectual level, the better the results obtained in these tasks.

The other tasks did not show significant levels of correlation, showing that regardless of the intellectual condition, individuals with ASD have significant motor deficits. Motor assessments of ASD people have highlighted these deficits, which increasingly arises the need for interdisciplinary programs that include professionals specialized in the gross and fine motor area so that the motricity work can be offered efficiently and safely to this audience, enhancing their global development.

\section{CONCLUSIONS}

MABC-2 using made it possible to identify some adaptations that may favor motor assessment in ASD groups. Correlation tests between CPM scores and motor skills showed that the degree of intelligence seems to influence motor performance when only specific tasks are evaluated. However, in general scores, there is no such correlation. Based on the obtained data, the relevance of studies and assessments in the motor area for ASD children is considered, so that the needs for psychomotor support for this group can be characterized, minimizing the factors that may interfere with the motor tasks performance and, consequently, in their global development.

\section{REFERENCES}

${ }^{1}$ American Psychiatric Association. Diagnostic and statistical manual of mental disorders: DSM-5. 5. ed. Washington: American Psychiatric Publishing; 2013.

2 Rinehart N, McGinley J. Is motor dysfunction core to autism spectrum disorder? Developmental Medicine \& Child Neurology [Internet]. 2010 mar. 19;52(8):697-697. Disponível em: http://dx.doi.org/10.1111/j.1469-8749.2010.03631.x

3 Jeste SS. The neurology of autism spectrum disorders. Current Opinion in Neurology [Internet]. 2011 abr.;24(2):132-9. Disponível em: http://dx.doi.org/10.1097/ wco.0b013e3283446450

${ }^{4}$ Henderson SE, Sugden DA, Barnett AL. Movement Assessment Battery for Children - 2. Examiner's manual. 2nd ed. London: Pearson; 2007.

${ }^{5}$ Quintas RHR, Carvalho ACRD, Quedas CLR. Comparação do protocolo adaptado de avaliação motora utilizando a escala Movement Assessment Battery for Children (MABC-2) no TEA. Cadernos de Pós-Graduação em Distúrbios do Desenvolvimento 
[Internet]. 2018;18(1). Disponível em: http://dx.doi.org/10.5935/cadernosdisturbios. v18n1p66-82

${ }^{6}$ Valentini NC, Ramalho MH, Oliveira MA. Movement Assessment Battery for Children-2: Translation, reliability, and validity for Brazilian children. Research in Developmental Disabilities [Internet]. 2014 mar.;35(3):733-40. Disponível em: http://dx.doi. org/10.1016/j.ridd.2013.10.028

${ }^{7}$ Montoro APPN, Capistrano R, Ferrari EP, Reis MDS, Cardoso FL, Beltrame TS. Concurrent validation of the MABC-2 and Developmental Coordination Disorder Questionnaire-BR. J Hum Growth Dev [Internet]. 2016 abr. 28;26(1):74. Disponivel em: http://dx.doi. org/10.7322/jhgd.110421

8 PINHEIRO CL. Validade e confiabilidade da Movement Assessment Battery for Children 2a edição para crianças brasileiras de 4 a 8 anos de idade. Belo Horizonte. [Dissertação de Mestrado em Ciências da Reabilitação da Escola de Educação Física, Fisioterapia e Terapia Ocupacional] - Universidade Federal de Minas Gerais; 2015.

${ }^{9}$ Bakke HA, Sarinho SW, Cattuzzo MT. Adaptation of the MABC-2 Test (Age Band 2) for children with low vision. Research in Developmental Disabilities [Internet]. 2017 dez.;71:120-9. Disponível em: http://dx.doi.org/10.1016/j.ridd.2017.10.003

${ }^{10}$ Quintas RHR, Blascovi-Assis SM, Santos DCC. Motor Performance in children and adolescents with Autism Spectrum Disorders. IJIER [Internet]. 2018 out. 31;6(10):273-86. Disponível em: http://dx.doi.org/10.31686/ijier.vol6.iss10.1187

${ }^{11}$ Hill AP, Zuckerman K, Fombonne E. Epidemiology of autism spectrum disorders. In: Volkmar FR, Rogers SJ, Paul R, Pelphrey KA (Eds.). Handbook of Autism and Pervasive Developmental Disorders: Diagnosis, Development, and Brain Mechanisms. New York: Wiley; 2014. p. 57-96.

${ }^{12}$ Bandeira DR, Alves ICB, Giacomel AE, Lorenzatto L. Matrizes progressivas coloridas de Raven - escala especial: normas para Porto Alegre, RS. Psicol Estud [Internet]. 2004 dez.;9(3). Disponível em: http://dx.doi.org/10.1590/s1413-73722004000300016

${ }^{13}$ ANGELINI, AL et al. Matrizes Progressivas Coloridas de Raven: escala especial. Manual. São Paulo: CETEPP; 1999.

${ }^{14}$ Coster WJ, Mancini MC. Recommendations for translation and cross-cultural adaptation of instruments for occupational therapy research and practice. Rev Ter Ocup Univ São Paulo (On-line) [Internet]. 2015 abr. 24;26(1):50. Disponível em: http://dx.doi. org/10.11606/issn.2238-6149.v26i1p50-57

${ }^{15}$ Beaton DE, Bombardier C, Guillemin F, Ferraz MB. Guidelines for the Process of Cross-Cultural Adaptation of Self-Report Measures. Spine [Internet]. 2000 dez.;25(24):318691. Disponível em: http://dx.doi.org/10.1097/00007632-200012150-00014

${ }^{16}$ Matias A, Martins R. Vasconcelos. Formulário de registro da Banda Idade 2 (7-10 anos). London: Pearson; 2011.

17 Borsa JC, Damásio BF, Bandeira DR. Adaptação e validação de instrumentos psicológicos entre culturas: algumas considerações. Paidéia, Ribeirão Preto [Internet]. 2012 dez.;22(53):423-32. Disponível em: http://dx.doi.org/10.1590/s0103$863 \times 2012000300014$

18 Landis JR, Koch GG. The Measurement of Observer Agreement for Categorical Data. Biometrics [Internet]. 1977 mar.;33(1):159. Disponível em: http://dx.doi. org/10.2307/2529310

${ }^{19}$ Cohen J. Statistical Power Analysis for the Behavioral Sciences, Second Edition. New Jersey: Lawrence Erlbaum Associates; 1998.

${ }^{20} \mathrm{Liu} \mathrm{T}$, Breslin CM. Fine and gross motor performance of the MABC-2 by children with autism spectrum disorder and typically developing children. Research in Autism Spectrum Disorders [Internet]. 2013 out.;7(10):1244-9. Disponível em: http://dx.doi. org/10.1016/j.rasd.2013.07.002

${ }^{21}$ Craig F, Lorenzo A, Lucarelli E, Russo L, Fanizza I, Trabacca A. Motor competency and social communication skills in preschool children with autism spectrum disorder. Autism Research [Internet]. 2018 mar. 1;11(6):893-902. Disponível em: http://dx.doi. org/10.1002/aur.1939 
22 Bhat AN. Is Motor Impairment in Autism Spectrum Disorder Distinct From Developmental Coordination Disorder? A Report From the SPARK Study. Physical Therapy [Internet]. 2020 mar. 10;100(4):633-44. Disponível em: http://dx.doi.org/10.1093/ptj/ pzz190

${ }^{23}$ Cossu G, Boria S, Copioli C, Bracceschi R, Giuberti V, Santelli E, et al. Motor Representation of Actions in Children with Autism. Schmitz C, organizador. PLoS ONE [Internet]. 2012 set. 10;7(9):e44779. Disponível em: http://dx.doi.org/10.1371/journal. pone.0044779

24 LICARI MK et al. Prevalência de dificuldades motoras no transtorno do espectro do autismo: Análise de uma coorte de base populacional. Autism Research, [s.l.]. 2020;13(2)298-306.

\section{Acknowledgments}

This study was financed in part by the Coordenação de Aperfeiçoamento de Pessoal de Nível Superior - Brasil (Capes) - Finance Code PROEX № $1133 / 2019$ 